Универзитет у Београду, Филозофрски фракултет Одељење за фрилозофију, Београд

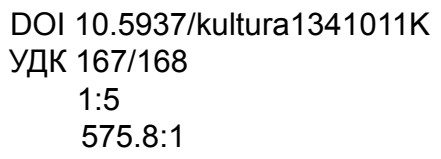

\title{
TPETA KYDTYPA:
} QИIO3OФИJA И HAVKA

\begin{abstract}
Сажетак: Синтагма 'трећа култура' створена је као ознака за активност научника и филозофа који филозофска питања настоје да артикулишу ослањајући се на резултате савремене природне науке и да одговоре на њих пруже у оквиру натуралистичке слике света. Циљ овог чланка је да се анализирају најважнији аспекти треће културе и одређене филозофске импликаиије ове конщепиије.
\end{abstract}

Кључне речи: трећа култура, теорија еволуичје, алтруизам, наука

Однос између различитих области знања у времену у коме је важење сваког општег оквира доведено у питање представља проблем од прворазредног значаја, и то не искључиво из теоријских разлога. ${ }^{1}$ Наиме, систем знања у коме се изражава наше актуелно тумачење света непосредно утиче на процес подучавања и организацију институција у којима се знање преноси и стиче. Свакако најсликовитији пример овог односа налазимо у строго канонизованој позицији схоластичког ученика: он седи сасвим доле, крај ногу свог учитеља који је ауторитативни извор знања. У овом моделу подучавања просторна дистанца између учитеља и ученика одговара хијерархијском поретку знања чији је крајњи извор трансцендентан. Понешто поједностављено, могло би се рећи да иза таквог модела стоји слика човека подређеног

1 Овај текст је настао у оквиру пројеката бр. 179041 (Динамички системи у природи и друштву: филозофски и емпиријски аспекти) и 41004 (Биоетички аспекти: морално прихватљиво у биотехнолошки и друштвено могућем), које финансира Министарство просвете и науке Републике Србије. 
сили која ограничава његове рационалне капацитете. Нововековна филозофија је, насупрот томе, у битном одређена односом према науци и она је афирмисала модел у коме је филозофија задужена за обезбеђивање чврстих темеља за сваки други тип знања: ако осигурамо основу која је несумњива, онда је довршење читаве грађевине знања само питање времена, а посао који треба да се обави има мање-више технички карактер.

Далеки одјеци оваквог схватања могу да се нађу и у савременом мотиву 'кризе темеља', према коме само филозофија може да разреши концептуалне тешкоће са којима се наука периодично суочава, а са којима она сама не може да се носи из сасвим принципијелних разлога. Међутим, ако ствари покушамо да сагледамо у другачијој перспективи, видећемо да наука по правилу не чека на разрешавање апстрактних концепцијских питања да би наставила са својим радом. Штавише, 'криза темеља' о којој филозофија тако радо говори када анализира положај и смисао науке више изражава нелагоду саме филозофије у погледу њеног места у грађевини знања него проблем који би битно успорио развој науке. Науци за њена објашњења није неопходна апсолутно монолитна концепцијска основа и зато филозофски рад на знању заиста пре може да се упореди са повременим реконструисањем брода који се налази на отвореном мору да би се обезбедила његова даља пловидба ${ }^{2}$ него са освајањем чврстог тла принципа које не угрожава морска измаглица. ${ }^{3}$ Другим речима, оквир из кога питање „Шта је човек?” данас црпи свој смисао у потпуности је измењен. Традиционална слика човека која се добрим делом темељила на идеји самосвесног субјекта чијем самосазнању припада повлашћена позиција, доведена је у питање експанзијом науке и новим концептом знања који претпоставља могућност објашњења у објективним терминима ${ }^{4}$. Пројекат треће културе

2 Ми смо као морнари који свој брод морају да дограђују на отвореном мору и који никада не могу да га раставе у пристаништу и да га поново изграде од најбољих саставних делова.”, Neurath, O. Protokollsätze, in: Carnap, R., Stöltzner, M. and Uebel, T. E. (2006) Wiener Kreis: Texte zur wissenschaftlichen Weltauffassung, Meiner Verlag, p. 401. О епистемолошком контексту и импликацијама ове метафоре у савременим анализама знања уп. Лазовић, Ж. (1994) О природи епистемичког оправдања, Београд, стр. 147.

3 Kritik der reinen Vernunft, (1904) Kants Werke III. Akademie-Ausgabe, Berlin, p. 294: „То је земља истине (примамљиво име), окружена пространим и узбурканим океаном, правим седиштем привида..." Кантовој метафори острва као чврстог тла знања одговара Фихтеова представа знања као грађевине која стоји на сигурним темељима.

4 „Не постоји тако нешто као што је наука у првом лицу, па, ако хоћете да имате науку о свести, она ће морати да буде наука о свести у трећем 


\section{EBA KAMEPEP}

представља покушај синтезе разнородних слика човека, покушај артикулисања једне синоптичке перспективе ${ }^{5}$ која би омогућила ново саморазумевање човека. Иако овде није могућа детаљна анализа свих аспеката концепције треће културе, покушаћу да издвојим основне елементе важне за разумевање њеног значаја и да на примеру схватања човека које се обликује на основама еволуционе теорије оцртам њен 'синоптички’ карактер.

\section{Научна слика човека и трећа култура}

Синтагма 'трећа култура' створена је као ознака за активност научника и филозофа који филозофска питања настоје да артикулишу ослањајући се на резултате савремене природне науке и да одговоре на њих пруже у оквиру једне нове, натуралистичке слике света. Овај покушај занимљив је и значајан из више разлога: после неколико деценија међусобног игнорисања у коме је филозофија за науку била бесплодна спекулација, а наука за филозофију израз редуковане слике света, филозофија и наука се опет налазе на заједничком путу дефинисања „дубљег значења нашег живота”, како то прегнантно каже творац израза 'трећа култура', амерички публициста Џон Брокман. ${ }^{6}$ Идеја треће културе је, осим тога, учинила очигледним колико је проблематично традиционално изједначавање културе са хуманистичким образовањем у свету у коме се највеће промене базирају на открићима у природним наукама и њиховој примени у техници. Управо одрећење 'трећа' за ову културу у настајању открива нам наведену димензију проблема: наиме, док научнике из прве половине 20. века, као што су Шредингер, Хајзенберг или Конрад Лоренц, без колебања схватамо као интелектуалце који нам говоре значајне ствари о човеку и његовом свету, у каснијим деценијама је јасно видљив јаз који постоји између научника, с једне стране, и интелектуалаца који су хуманистички образовани, са друге. Овде не можемо да анализирамо узроке дубоког јаза између мислилаца који се баве природним и оних који се баве хуманистичким наукама, ови узроци су, свакако, везани и за неупоредиво увећање знања о природи чији смо сведоци, као и за све већу специјализацију која је из тога произашла. У згради знања, да се послужим већ поменутом Фихтеовом метафором, изграђено је толико

лицу...“, Dennett, D. С. (2005) Sweet Dreams, Philosophical Obstacles to a Science of Consciousness, London, p. 148.

5 Sellars, W. (1963) Philosophy and the Scientific Image of Man, in: Science, Perception and Reality, Atascadero, California, p. 1.

6 Brockman, J. (1996) Die dritte Kultur, Das Weltbild der modernen Naturwissenschaft, München, p. 18. 


\section{EBA KAMEPEP}

много просторија да је за човека постало незамисливо и да посети сваку од њих, а камоли да се у свима њима одомаћи. Чини се, међутим, да овај јаз има једну значајну последицу коју бих овде желела само да поменем, а то је известан конзервативизам који је карактеристичан за став да у питањима смисла хуманистички интелектуалци имају апсолутни монопол. Трећа култура представља концепцију која недостатке оваквог става покушава да премости тако што отвара један нови хоризонт у коме ова питања можемо да поставимо. Она, међутим, не представља некакав амалгам у коме је превазиђен недостатак комуникације између два облика култуpe, тј. знања, оног литерарног и оног природно-научног, већ се обликује кроз нове форме интелектуалног дискурса у коме »природна наука постаје јавна култура«. Природна наука, наиме, више није само скуп специјалистичких теорија и експерименталних процедура које немају никаквог непосредног додира са питањима смисла и вредности која су од темељне важности за човеков живот. Она, напротив, у форми треће културе кроз непосредно обраћање широкој читалачкој публици жели управо да се изјасни о овим питањима. Иако овај феномен често видимо само као популаризацију науке и можда као један од облика масовне културе, хтела бих овде да истакнем неколико момената за које мислим да су од значаја за савремено редефинисање односа између филозофије и науке под утицајем идеје треће културе.

Пре нешто више од 150 година творац теорије еволуције, Чарлс Дарвин, изразио је наду да ће једна концепцијски изграђена историја природе пружити одговоре на многа важна питања традиционалне метафизике, да ће нам ова историја кроз утврђивање наше генеалогије објаснити нашу „суштину" и специфичност наших веза са природом коју смо често схватали као некакав обавезујући поредак и извор вредности. ${ }^{7}$ Иако су ове наде, свакако, биле претеране, ново схватање природе пружило је могућност да се стара питања поставе у јединственој перспективи која се све јасније обликује. Неколико представа је карактеристично за овакво виђење света: то је, пре свега, представа да свет није статичан, да он не поседује вечну суштину, већ да се развија у времену. Овај развој, међутим, није усмерен према неком циљу нити су се комплексне творевине које налазимо у природи нужно развиле из оних једноставнијих. Свет се види као комплексан, у њему је владајући принцип самоорганизације, а ствари у

7 „Човеков постанак је сада доказан. Метафизика мора да напредује. Онај ко разуме бабуна, учиниће више за метафизику него Лок.", Notebook M (Metaphysics on Morals and Speculations on Expressions 1838), (1987) Charles Darwin's Notebooks, Cambridge. 
свету се односе једна на другу, чиме учење о апсолутним својствима постаје излишно. Развија се представа да се природа састоји од импровизованих апарата и необичних механизама који, иако врло често пуни грешака и несавршености, обезбеђују не само опстанак света, већ и његове специфичне естетске квалитете, оно што доживљавамо као лепоту у природи. Када говорим о представама које су карактеристичне за ово ново виђење света, онда тиме не желим да сугеришем да постоји некакво монолитно тумачење које деле сви научници и филозофи који себе виде као део овакве концепције науке и филозофије. Напротив, плуралност је битна одлика треће културе: као што не постоји хијерархија проблема по важности, тако више не постоји ни могућност да филозофија себе одреди кроз супротност у односу на науку. ${ }^{8}$ Јер, управо питања која су израсла у граничним подручјима сазнања у појединим наукама условила су полагано обликовање специфичног модела филозофије која себе не види ни као утемељење науке ни као апстрактно свођење научних увида на мали број принципа. Насупрот фихтеовској дедукцији начела сваке могуће науке из темељних начела свег људског знања, у трећој култури је комуникација између просторија у згради знања обезбеђена овим додирима граничних области или интердисциплинарним приступом.

Оно што, међутим, у идеји треће културе сматрам најзанимљивијим јесу њене сличности и разлике у односу на природнофилозофску традицију 17. века. $^{9}$ Она, делом, може да се схвати као специфичан покушај обнављања овакве традиције, пре свега у погледу успостављања нових веза између филозофије и природне науке. Читава новија филозофиja, почев од ренесансе, налази се под утицајем математичке природне науке, коме нису могли да измакну ни емпиризам ни рационализам, а ни идеалистички ни реалистички усмерено мишљење. Непосредна последица потискивања грчког и средњовековног схватања природе путем Галилејевог модерног схватања је било и видно маргинализовање мисаоних токова који потичу од Платона и Аристотела, а

8 Упореди: Die dritte Kultur, p. 34.

9 Један од аутора 'треће културе', Ли Смолинг, ову релацију између филозофије и науке изражава на следећи начин: „Када сам врло оптимистичан, ја запажам неку врсту препорода природнофилозофске традиције, која се, међутим, заснива на једној новој слици света која је сасвим другачија од слике коју су имали филозофи природе у 17. веку.”, исто. Претходно сам издвојила основне карактеристике ове нове слике света, и, нема сумње да се она разликује од седамнаестовековног схватања природе, али, у погледу односа између филозофије и природне науке, сличност је више него уочљива. 
који су до тада у битном обележавали западно мишљење. Учење о идејама скупа са супстанцијалним формама скоро потпуно је стављено у страну када је завладало ново тумачење система природе. Ни сам Лајбниц који је свесно тежио да се поново надовеже на грчку филозофију и који је у својим монадама поново оживео аристотеловске ентелехије, монаде разумева као неку врсту последњих делова целине природе, а не као логичке суштине. Исходиште његове филозофије које одређује његове темељне појмове, одређено је кроз природну науку, и сасвим је видљива једна јединствена тенденција да метафизика израста из природне науке, а не из ослањања на логику. За седамнаестовековну метафизику може се рећи да је под одлучујућим утицајем природне науке. Однос између филозофије и природне науке добија нешто другачији карактер у Кантовој критичкој филозофији, која, свакако, јесте окренута науци свог времена и кроз анализу њених категорија и исказа покушава да утврди услове могућности сваког сигурног сазнања, али у којој, истовремено, наука има амбивалентну позицију: наука се истовремено појављује и као сазнајни узор, али и као сазнајна творевина којој је потребно филозофско утемељење. Кант и у Критиции чистог ума и у Критици моћи суђења успева да хармонично одржи оба схватања науке, међутим, чини се да је ово извор каснијих дивергентних струја у схватању природе науке. Већ код Фихтеа се све више наглашава други аспект на рачун првог, наиме, иако се Фихте позива на науку, конкретно на геометрију, као на узор у погледу евидентности, само филозофија има приступ изворном акту сазнања на коме се заснива и научно сазнање. Оно што је још важније јесте чињеница да ни код једног ни код другог наука више не може бити непосредан извор слике света коју филозофија следи. Ова тенденција ће у многим важним филозофским школама постајати све наглашенија: разлике између филозофије и науке ће постати тако начелне да ће током дугог периода једна другу само доводити у питање. Чини се, међутим, да актуелна кретања опет отварају могућност једног комплекснијег и плоднијег дијалога између филозофије и природне науке чији резултат ће бити специфична синтеза, по много чему упоредива са оном седамнаестовековном.

Природа односа који се успостављају између филозофије и науке врло јасно се може ишчитати и из развоја појединачних филозофских дисциплина и ту можемо пронаћи још један аргумент у прилог тези да природна наука може опет постати извор филозофске слике света и човека. Начин на који се филозофија науке трансформисала током 20. века је један од најбољих примера. Филозофија науке током неколико деценија свог развоја била је усмерена углавном 


\section{EBA KAMEPEP}

на методолошка питања која су се постављала у вези са науком, а физика је важила као једина „тврда” наука, како се то у савременом жаргону каже. Другим речима, физика је једина задовољавала претпоставке које је у филозофију науке унео логички емпиризам, а то значи да је представљала тип знања који је био слободан од метафизички и епистемолошки сумњивих појмова ${ }^{10}$. Филозофија науке је у овој фази свог развоја све типове знања покушавала да редукује на онај који налазимо у физици, и тиме је, парадоксално, у извесном смислу пресецала везу између филозофије и науке. Тек од момента када се филозофија поново окренула решавању концептуалних проблема везаних за конкретна научна питања, она је поново добила приступ науци као извору увида од филозофског значаја и отворила пут за једну обухватну трансформацију појединих филозофских дисциплина. Довољно је поменути савремену тенденцију натурализма у епистемологији и етици, па да нам буде јасно да, иако наука можда не може непосредно да пружи одговоре на филозофска питања, ова питања никако не могу да буду разрешена мимо науке.

Какву нам, коначно, слику света и човека нуди трећа култура? Схватање света као променљивог и комплексног изгледа да нам намеће нерешиве проблеме: плуралност перспектива, од којих су неке међусобно неспојиве, нарушава јединственост човековог саморазумевања. С друге стране, слика човека која успева да избегне ове тешкоће толико је уопштена и сиромашна да више ништа важно не може да нам објасни. Али, зашто уопште о нашем разумевању света и човека говоримо у терминима слике и перспективе? Управо за неке од најзначајнијих представника ${ }^{11}$ треће културе идеја промене перспективе била је одлучујућа за формулисање нове концепције знања коју трећа култура представља. Адекватност слике коју поседујемо о свету зависи од адекватности перспективе у којој свет посматрамо и од тога да ли чињенице можемо да опишемо на неутралан начин. Један од важних утицаја природне науке на филозофију може да се види и у томе што неутралност (перспектива трећег лица, како Денет то назива) постаје незаобилазан захтев који се поставља и филозофији. Од истинског домашаја ове идеје зависи, заправо, и могућност једне обухватне, синоптичке слике човека.

10 Sarkar, S. and Pfeifer, J. (eds.) (2006) The Philosophy of Science, New York, p. 556.

11 Dennett, D. C. (1991) Consciousness Explained, New York, Boston, London, p. 66. 


\section{'Синоптичка' перспектива треће културе}

Основно обележје „појавне слике човека”"12, као и слике човека карактеристичне за филозофску традицију која себе одpeђује као philosophia perennis јесте да он себе и друге види као личности. ${ }^{13}$ На овом односу заснива се његово тумачење света, а појам личности је базичан и не подлеже даљој анализи. Слобода воље и одговорност за сопствене поступке су неки од незаобилазних елемената оваквог схватања. Садржаји човекове свести изражавају се у појмовима путем којих он може на одговарајући начин да представи догађаје у свету. Оно што је, међутим, од посебног значаја за ову слику јесте да се свет у њој представља онако како нам је он дат кроз садржаје наше свести, дакле у битном везан за опажене објекте. Научне теорије, насупрот томе, постулирају „објекте и догађаје који не могу да се опажају да би објаснили корелације између оних који могу да се опажају." ${ }^{14}$ Дакле, разлика између појавне и научне слике човека може да се сведе на следеће: прва концепција се ограничава на оно што може да се каже о догађајима доступним опажању и интроспекцији, док друга постулира неке догађаје да би објаснила оне који су нам доступни унутар појавне слике. У овој другој концепцији човек се схвата као „физички систем састављен од једноставних компоненти"15 које су спојене у врло комплексан систем, конструисан на основу генетичког плана који је селектован у еволуцији под утицајем многобројних срединских варијабли. Дакле, у научним теоријама се човек суштински појављује као објект. У таквој перспективи се ни језик ни појмовна структура менталних догађаја не претпостављају, већ се тумаче као резултат дугог еволуционог процеса и развоја који је групни феномен (нпр. плес пчеле као облик комуникације који еволуционо претходи људском језику).

Покушаћу да у основним цртама представим проблем који је, из сасвим разумљивих разлога, нарочито важан и чије сагледавање из перспективе „еволуционе идеје” која представља један од најзначајнијих елемената концепције треће културе добија једно ново значење. Ова кратка анализа

12 Анализа која следи ослања се на разликовање између појавне и научне слике човека (manifest and scientific image of man) које је увео амерички филозоф В. Селарс у свом есеју Филозофија и научна слика човека (1963). Мотив различитих слика човека након њега је постао један од доминантних у америчкој филозофији, као и покушај да се пронађе могућност уједињавања ових слика.

13 Упореди: Sellars, W. исто, стр. 18.

14 Исто, стр. 19.

15 Исто, стр. 29. 
требало би да илуструје тешкоће са којима смо суочени када настојимо да у оквиру научне културе артикулишемо јединствену слику света и човека. Ради се о проблему алтруизма. Антрополошке представе традиционално укључују моменат разликовања добра и зла: човек се од животиње разликује, између осталог, и по томе што зна шта је добро, а шта зло. Чињење добра у људском свету је високо вредновано, нарочито ако имплицира извесне личне штете. Алтруизам, сасвим сигурно, чини највреднији део наше људске самосвести. ${ }^{16}$ Питање је, међутим, да ли и слика човека чије обрисе налазимо у еволуционој биологији изгледа овако? У научној слици реалност алтруизма се не оспорава непосредно. Дакле, несумњиво постоје поступци које смо спремни да окарактеришемо као алтруистичне. Али, оно што је ново је да се ови поступци посматрају и тумаче искључиво у категоријама својих ефеката. Да бисмо разумели проблем, неопходно је да укратко размотримо специфичност еволуционистичког објашњења. Наиме, ово објашњење почива на принципу природне селекције и оно нам, начелно, у погледу алтруизма говори следеће: ако природна селекција фаворизује јединке са вишом адаптивном вредношћу, тј. оне које поседују особине које им повећавају шансе за преживљавање и размножавање, а алтруистичним чином, по дефиницији, повећавамо адаптивну вредност друге јединке на рачун своје сопствене, логично је очекивати да ће природна селекција да делује против алтруизма. Чињеница постојања алтруизма у људској заједници, додуше, не мора да представља проблем који се опире сваком објашњењу: у крајњој линији, увек можемо да посегнемо за трансцендентним извором који нам љубав према ближњем налаже као највиши израз људскости и специфичне различитости човека у односу на друга природна бића. Али, еволуциона биологија суочава нас са питањем на које није тако лако одговорити: наиме, понашање које можемо да назовемо алтруистичним срећемо и код животиња какве су социјални инсекти, као и код виших примата.

Филозофи и научници су овај проблем покушавали да разреше на различите начине, пре свега разликовањем психолошког од еволуционог алтруизма. Док у случају психолошког алтруизма имамо свесну намеру да унапредимо интересе неке друге личности на рачун својих сопствених интереса, биолошки алтруизам односи се искључиво на

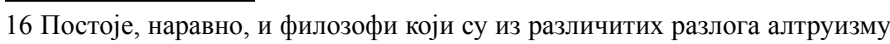
приписивали врло малу вредност, као што су Кант и Ниче, али чини се да то ипак није битније утицало на наше уобичајено високо вредновање алтруизма. 
последице поступака и њихове ефекте на адаптивну вредност јединки које чине и примају алтруистичан акт. На први поглед је јасно да је овакав начин посматрања у значајној супротности са нашом интуицијом и нашим склоностима, јер смо навикли да људима приписујемо неку интринсичну вредност независно од специфичних ефеката њихових поступака: тако се особи приписују морални квалитети, нпр. доброта, зато што је на одређени начин настројена, а не зато што сви њени поступци имају „добре” ефекте. Оно што нас, заправо, у овом случају испуњава нелагодом је могућа веза између еволуционог алтруизма и психолошког алтруизма који има морално значење. Ни приговор антропоморфизма у овом случају не значи много: није важно да ли неки појам можемо да применимо само на феномене карактеристичне за људско друштво или и на организацију животињских заједница, већ да ли можемо да им припишемо морално значење какво они примарно имају у првом случају.

То постаје сасвим јасно када имамо у виду једно од могућих еволуционистичких тумачења постанка морала. Наиме, ако је у току историје природе сачувано само оно што је адаптивно, онда је и алтруизам који је сачуван и развијен морао да има адаптиван смисао. Али, како алтруизам који значи увећање туђих шанси за преживљавање на рачун својих сопствених, може да се тумачи као адаптиван? Одговор који се намеће је да је алтруизам нешто сасвим друго од онога што себи уобичајено представљамо. Парадоксално, он би морао да буде нека врста себичности. Ако ову аналитичку схему применимо на релацију између родитеља и деце, која се обично схвата као израз несебичности, барем што се тиче родитељских поступака, добијамо следеће тумачење: иако се као родитељи понашамо алтруистично према својој деци (и наши свесни мотиви су алтруистични), ми, заправо, на тај начин радимо у корист својих гена који се налазе у телима наше деце. За наше гене је корисније да се понашамо алтруистично према телима у којима се они налазе, него да се понашамо компетитивно. ${ }^{17}$ Уколико овој ситуацији покушамо да дамо опште значење, наши свесни алтруистични мотиви постоје само зато да би давали подстицај нашим себичним диспозицијама. Природа нас је обликовала тако да верујемо у дезинтересирани морални код који нам налаже да помажемо другима, а морал је илузија која је неопходна да бисмо били наведени на кооперацију у ситуацијама у којима је она кориснија од себичног понашања. Укључивањем мотива илузије и самообмане премошћује се јаз између хетерогених

17 Trivers, R. (2002) Natural Selection and Social Theory: Selected Papers of Robert Trivers, Oxford University Press, p. 56. 


\section{EBA KAMEPEP}

подручја природе и морала и предупређује се евентуални приговор натуралистичке грешке: природа је та која је обезбедила илузију човекове моралне аутономије да би његово деловање у складу са сопственим интересима учинила ефикаснијим. ${ }^{18}$ Интуитивна одбојност коју осећамо према оваквом покушају објашњења људског морала и слободе воље као илузије која је неопходна да бисмо себично, тј. адаптивно поступали, почива, свакако, и на нашој дубокој потреби да заиста будемо добри и саосећајни, а не да само тако делујемо. Алтруизам се управо и објашњава изостанком калкулисања. Међутим, наука је недвосмислено показала да све оно што чини човека стоји у суштинској вези са његовим еволуционим развојем и да филогенетска перспектива може бити од извесне важности и за разумевање његових моралних вредности. Наиме, ако су наше диспозиције да се морално понашамо донекле условљене и нашим еволуционим наслеђем, онда и питање о моралу мора да добије нову форму: како смо (као врста) могли да научимо да будемо бољи?

Моћ природне науке да трансформише наше традиционалне представе о нама самима и о свету чини се да је сасвим недвосмислена, или, барем, много извеснија од њене моћи да непосредно пружи одговоре на филозофска питања. Међутим, иако не можемо да будемо потпуни оптимисти у погледу могућности помирења уобичајене концепције човека са научним разумевањем људске природе ${ }^{19}$, блискост филозофије и науке која се негује у трећој култури обезбеђује нам да се ослободимо тобож кохерентне, а заправо врло редуковане слике човека коју нам нуди хуманистички опседнута „друга култура”. А ослобађање од илузије да поседујемо потпуно знање свакако је незаобилазна етапа у нашем истраживању света.

18 Елемент самообмане конститутиван је и у Ничеовом објашњењу хришћанског морала. Илузија и код њега такође има витални карактер, јер хришћанин, односно човек ропског морала само под претпоставком сопственог моралног савршенства, које укључује и љубав према непријатељу, може да преживи у конфронтацији са аристократом и да га савлада. Неки од значајних филозофа биологије склони су да морал и идеју слободе воље тумаче као корисну, штавише неопходну илузију. Упореди: Ruse, M. and Wilson, E. O. The Evolution of Ethics, in: Philosophy of Biology ed. Ruse, M. (1998) New York, p. 316.

19 Zawidzki, T. (2007) Dennett, Oxford, p. 153. 


\title{
EBA KAMEPEP
}

\section{ЛИТЕРАТУРА:}

Brockman, J. (1996) Die dritte Kultur, Das Weltbild der modernen Naturwissenschaft, München

Carnap, R. Stöltzner, M. and Uebel, T. E. (2006) Wiener Kreis: Texte zur wissenschaftlichen Weltauffassung, Meiner Verlag

Darwin, C. (1987) Notebook M (Metaphysics on Morals and Speculations on Expressions 1838), Cambridge

Дарвин, Ч. (1948) Постанак врста, Београд

Dennett, D. C. (1991) Consciousness Explained, New York, Boston, London

Dennett, D. C. (2005) Sweet Dreams, Philosophical Obstacles to a Science of Consciousness, London

Kant, I. (1904) Kritik der reinen Vernunft, Berlin: Kants Werke III, Akademie-Ausgabe

Лазовић, Ж. (1994) О природи епистемичког оправдањ $а$, Београд

Ruse, M. and Wilson, E. O. The Evolution of Ethics, in: Philosophy of Biology, ed. Ruse, M. (1998) New York

Sarkar, S. and Pfeifer, J. (2006) The Philosophy of Science, New York

Sellars, W. (1963) Philosophy and the Scientific Image of Man, in: Science, Perception and Reality, California, Atascadero

Trivers, R. (2002) Natural Selection and Social Theory: Selected Papers of Robert Trivers, Oxford University Press

Zawidzki, T. (2007) Dennett, Oxford

Eva Kamerer

University of Belgrade, Faculty of Philosophy Department of Philosophy, Belgrade

\section{THE THIRD CULTURE: PHILOSOPHY AND SCIENCE}

\begin{abstract}
The phrase 'third culture' was created to denote activities of scientists and philosophers who try to articulate philosophical questions based on the results of natural sciences and to provide answers under the framework of naturalism. The aim of my paper is to analyse the most important aspects of the third culture and some philosophical implications of that conception.
\end{abstract}

Key words: third culture, theory of evolution, altruism, science 